\title{
Ocena przewodnictwa w nerwie słuchowym i pniu mózgu za pomocą metody ABR u osób z zespołem Downa
}

\section{Evaluation of conductivity in the auditory nerve and brain stem by the ABR method in people with Down syndrome}

\author{
Katarzyna Sienkiewicz' ${ }^{1}$ Krzysztof Kochanek ${ }^{2,3}$, Adam Piłka² \\ ${ }^{1}$ Centrum Diagnozy i Terapii „Usłyszeć siebie”, Lublin \\ ${ }^{2}$ Instytut Fizjologii i Patologii Słuchu, Światowe Centrum Słuchu, Warszawa/Kajetany \\ ${ }^{3}$ Uniwersytet Marii Curie-Skłodowskiej, Zakład Logopedii i Językoznawstwa Stosowanego, Lublin
}

Adres autora: Katarzyna Sienkiewicz, Centrum Diagnozy i Terapii „Usłyszeć siebie”, ul. Wapowskiego 4/Lok.1, 20-491 Lublin, e-mail: sienkiewicz_katarzyna@interia.pl

\section{Streszczenie}

Wprowadzenie: Jedną z przyczyn opóźnień w rozwoju intelektualnym, poznawczym i językowym u dzieci z zespołem Downa (ZD) są zaburzenia słuchu. Szacuje się, że częstość występowania ubytków słuchu u dzieci z tym zespołem wynosi od 38\% do $82 \%$. Wielu badaczy zainteresowało się pomiarami wartości interwałów czasowych odpowiedzi ABR u pacjentów z zespołem Downa, zakładając, że z różnych powodów przewodnictwo w nerwie słuchowym jest różne od przewodnictwa u pacjentów zdrowych.

Cel: Celem pracy była ocena przewodnictwa w nerwie słuchowym i pniu mózgu u osób z zespołem Downa za pomocą słuchowych potencjałów wywołanych pnia mózgu.

Materiał i metody: W badaniach wzięło udział 39 osób z zespołem Downa w wieku od 1 roku do 27 lat. Grupa kontrolna obejmowała 78 osób z prawidłowym słuchem w wieku od 1 roku do 35 lat. Badanie ABR dla trzasku o natężeniu 70-80 dB nHL przeprowadzono za pomocą urządzenia Integrity V500 firmy Vivosonic. Pasmo wzmacniacza biologicznego w badaniach ABR zawierało się w przedziale od 30 do $3000 \mathrm{~Hz}$. Bodźce prezentowano z naprzemienną polaryzacją przez słuchawki ER-3A. Częstość powtarzania bodźca wynosiła 37/s. W odpowiedziach ABR analizowano wartości interwałów czasowych I-III i III-V.

Wyniki: Średnia wartość interwału I-III w grupie kontrolnej była istotnie statystycznie dłuższa niż w grupie osób z zespołem Downa, natomiast interwał III-V w grupie kontrolnej był nieznacznie krótszy niż w grupie z ZD, ale w sposób nieistotny statystycznie. W obu grupach średnie wartości interwału I-III były istotnie statystycznie dłuższe niż wartości średnie interwału III-V.

Wnioski: Wyniki niniejszej pracy wykazały, że przewodnictwo neuronalne w nerwie słuchowym u osób z zespołem Downa jest szybsze od przewodnictwa osób zdrowych z prawidłowym słuchem.

Słowa kluczowe: ABR • zespół Downa • zaburzenia słuchu

Abstract

Introduction: One of the reasons for delays in intellectual, cognitive and linguistic development in children with Down syndrome are hearing problems. It is estimated that $38 \%$ to $82 \%$ children with Down syndrome suffer from hearing loss. Researchers got interested in the measurement of time intervals of ABR responses in patients with Down syndrome, assuming the conductivity of the auditory nerve is different than conductivity in healthy patients.

Objective: The aim of this study was to evaluate the conductivity of the auditory nerve and brain stem in people with Down syndrome using auditory brainstem evoked potentials.

Material and methods: The study involved 39 people with Down syndrome aged from 1 to 27 years old. The control group consisted of 78 people with normal hearing in the age from 1 to 35 years old. ABRs for a click with an intensity of $70-80 \mathrm{~dB}$ $\mathrm{nHL}$ was performed with the use of Integrity V500's Vivosonic system. The biological amplifier bandpass filter was in the range 
of 30 to $3000 \mathrm{~Hz}$. Stimuli were presented with alternating polarity by using earphones ER-3A. The stimulus repetition rate was $37 / s$. In the ABR there were analyzed response values of intervals I-III and III-V.

Results: The mean value of the interval I-III in the control group was significantly longer than in patients with Down syndrome. The interval III-V in the control group was slightly shorter than in the group with Down syndrome. But this difference was not significant. In both groups the mean values of the interval I-III were significantly longer than the average interval III-V.

Conclusions: The results of this study showed that neuronal transmission in auditory nerve in subjects with Down syndrome is faster as compared to healthy people with normal hearing.

Key words: ABR • Down syndrome • hearing impairment

\section{Wstęp}

Zaburzenie rozwojowe określane jako zespół Downa powstaje w wyniku nieprawidłowej embriogenezy na skutek dodatkowego chromosomu 21 pierwszej pary (lub jego długich ramion), którego obecność potwierdza się w badaniu kariotypu. Aberracje chromosomowe w zespole Downa mogą mieć charakter liczbowy lub strukturalny. Można wyróżnić trzy postaci zespołu Downa: trismomię prostą, trisomię translokacyjną i mozaicyzm. Dodatkowy materiał genetyczny powoduje zaburzenia metaboliczne, liczne wady narządów wewnętrznych, typowe cechy fenotypowe, zaburzenia niektórych zmysłów oraz różnego stopnia upośledzenie psychoruchowe [1-3]. Jedną z przyczyn opóźnień w rozwoju intelektualnym, poznawczym i językowym u dzieci z zespołem Downa są zaburzenia słuchu. Szacuje się, że częstość występowania ubytków słuchu u dzieci z ZD wynosi od $38 \%$ do $82 \%$ [4,5]. Wielu badaczy zgadza się, że najczęściej występującym rodzajem niedosłuchu u dzieci z zespołem Downa jest niedosłuch przewodzeniowy, jednak inne źródła wskazują także na niedosłuch mieszany lub czuciowo-nerwowy [6-17]. Wady twarzoczaszki oraz nieprawidłowy przebieg trąbek słuchowych u osób z zespołem Downa są przyczyną zwiększenia zachorowalności na zapalenie ucha środkowego, zapalenie gardła oraz zatok przynosowych. Wąski przewód słuchowy zewnętrzny może utrudniać wykonanie otoskopii za pomocą standardowych wzierników. Liczni autorzy stwierdzają, że niedosłuchy $\mathrm{u}$ dzieci z zespołem Downa spowodowane są zaburzeniami zlokalizowanymi w uchu środkowym [6-9,11-13]. Sugeruje się, że przyczynami ubytków słuchu u dzieci z zespołem Downa są: zagęszczona woskowina uszna, częste wysiękowe zapalenia ucha środkowego oraz nieprawidłowości wentylacyjne i mechaniczne ucha środkowego.

Anomalie rozwojowe u osób z zespołem Downa mogą wpłynąć na pracę układu nerwowego, w tym także narządu słuchu. U dzieci z ZD występują w różnym stopniu upośledzenia umysłowe, wraz $\mathrm{z}$ wiekiem obserwuje się demencję o wczesnym początku neurodegeneracji. Możemy również zaobserwować dysmorfogenezę korową, spowolnienie prenatalnej neurogenezy oraz efekty pre- i postnatalnej synaptogenezy. W każdym przypadku ZD obserwujemy opóźnienie wzrostu mózgu, którego objętość i masa są zdecydowanie mniejsze niż u ludzi zdrowych. Różnica wzrasta wraz z wiekiem do $50 \%$ w porównaniu $\mathrm{z}$ rówieśnikami z odpowiednim kariotypem [3,17-24]. Już od 24 tygodnia życia możemy zaobserwować u dzieci z ZD uproszczenie wzoru ścieńczałych zakrętów mózgowych z poszerzeniem bruzd, nieprawidłowym rozwojem trzeciorzędnych zakrętów czołowych i górnych ciemieniowych wraz z nieprawidłowym wykształceniem drugorzędnych bruzd. Mózg osób z ZD cechuje się spłaszczeniem w wymiarze przednio-tylnym, skróceniem długości czołowo-potylicznej półkul mózgowych wskutek niedorozwoju płatów potylicznych i czołowych, stromym nachyleniem płatów potylicznych, zmniejszonym hipokampem oraz spoidłem przednim, hipoplastycznie zmniejszonym pniem mózgu i móżdżku [3,17-24]. W momencie urodzenia dziecka z ZD kora mózgowa posiada o 20-50\% mniejszą liczbę neuronów, jest to widoczne w liczbie komórek nerwowych II i IV warstwy korowej w polu 10, 17, 22. Odkryto podczas badania gęstości synaptycznej, że jest ona największa w wieku 8 miesięcy i obniża się w ciągu następnych 9 lat - w tym wieku osiąga ona wartość, jaka występuje u osoby dorosłej [22].

Do momentu wprowadzenia metod elektrofizjologicznych ocena słuchu u pacjentów z zespołem Downa była bardzo trudna lub nawet niemożliwa. W ostatnich latach pojawiły się w piśmiennictwie nowe prace dotyczące oceny zaburzeń słuchu u dzieci z zespołem Downa, w których zastosowano metodę słuchowych potencjałów wywołanych pnia mózgu - ABR. Za pomocą tej metody można wyznaczyć nie tylko wielkość ubytku słuchu, lecz także ocenić przewodnictwo w nerwie słuchowym (interwał I-III) lub w pniu mózgu (III-V) [26]. Suma wartości tych interwałów daje informację o łącznym przewodnictwie w nerwie słuchowym i pniu mózgu. Patologie pozaślimakowe, które mogą występować zarówno w nerwie słuchowym jak i pniu mózgu, mogą zaburzyć przewodnictwo neuronalne, czego efektem może być wydłużenie jednego lub obu interwałów. Jeżeli patologia pozaślimakowa prowadzi do zaburzenia przewodnictwa w nerwie słuchowym, to efektem jest wydłużenie interwału I-III.

Wielu badaczy, np. Kręcicki [36], Roizen [12], Pilecki [14], zainteresowało się pomiarami wartości interwałów czasowych odpowiedzi ABR u pacjentów z zespołem Downa, zakładając, że przewodnictwo w nerwie słuchowym jest różne od przewodnictwa u pacjentów zdrowych. Niektórzy z nich wskazywali na wydłużenie interwału I-III, inni natomiast na skrócenie wartości interwałów I-III i III-V [27-35].

Jako przyczynę skrócenia interwału I-III Squires i wsp. [28] wskazywali na krótszą drogę od ślimaka do jąder ślimaka. Diaz i Zuron [29] przypisują fakt zmianom w ślimaku lub drodze słuchowej. Ferri i wsp. [30] stwierdzili, że przyczyną mogą być zahamowania lub pobudzenia centralnego układu nerwowego. Według Jiang i wsp. [31] 
krótsze interwały I-V mogą być sygnałem nieprawidłowego przewodzenia nerwowego w pniu mózgu, a tym samym odzwierciedlać nieprawidłowy rozwój pnia mózgu. Kakigi i Kuroda [32] w swojej pracy przytoczyli trzy hipotezy dotyczące skrócenia interwału I-V: szybsze przewodzenie we włóknach nerwowych, mniejsze rozmiary pnia mózgu oraz deficyty w ślimaku. Crome i wsp. [33] stwierdzili, że wielkość pnia mózgu i móżdżku u osób z zespołem Downa stanowiła tylko 66\% prawidłowej masy, co mogło wpływać na szybsze przewodzenie impulsów. Poblano i wsp. [34] sugerowali, że skrócenie transmisji impulsów nerwowych w ośrodkowym układzie nerwowym u pacjentów z zespołem Downa może być spowodowane małogłowiem, przyspieszoną depolaryzacją i repolaryzacją neuronów. Intrapiromkul i wsp. [35] zwrócili uwagę na anomalie w budowie ucha wewnętrznego u noworodków z zespołem Downa, takie jak zniekształcenie wysepek kostnych kanału półkolistego bocznego, wąskie kanały słuchowe wewnętrzne, zwężenie kanału nerwu ślimakowego, rozejście się kanałów półkolistych i poszerzenie wodociągu przedsionka. Wg tych autorów anomalie te mogły istotnie wpłynąć na wyniki badań słuchowych potencjałów wywołanych pnia mózgu. Interesujące badania przeprowadzili Saliba i wsp. [40], którzy analizowali u osób z zespołem Downa związek pomiędzy stanem słuchu, ocenionym na podstawie wyników badania emisji otoakustycznych i słuchowych potencjałów wywołanych pnia mózgu dla trzasku, oraz zmianami anatomicznymi w zakresie ucha zewnętrznego, środkowego, a w szczególności ucha wewnętrznego, ocenionymi na podstawie wyników tomografii komputerowej o wysokiej rozdzielczości. W badaniach udział wzięło 17 pacjentów w wieku od 7 do 23 lat. Wyniki ABR nie wskazały na wydłużenie latencji fal I, III, V. Wymiary ślimaka, przedsionka, przewodu słuchowego zewnętrznego i wewnętrznego były mniejsze niż w grupie kontrolnej, natomiast zaobserwowano powiększenie szerokości wodociągu ślimaka u osób z ZD oraz zmniejszenie średnicy przewodu słuchowego wewnętrznego [40]. Istotne, choć niezbyt silne korelacje stwierdzono pomiędzy progiem fali V oraz długością przewodu słuchowego wewnętrznego i wymiarami przedsionka.

Z uwagi na znaczne rozbieżności w wynikach prac różnych autorów dotyczących oceny przewodnictwa w nerwie słuchowym i pniu mózgu u osób z zespołem Downa przeprowadzonej za pomocą słuchowych potencjałów wywołanych pnia mózgu w niniejszej pracy podjęto własne badania dotyczące tego zagadnienia.

\section{Materiał i metody}

\section{Materiał}

W badaniach wzięło udział 39 osób z zespołem Downa w wieku od 1 roku do 27 lat (śr. 10,7 $\pm 5,2$ lat), w tym 19 chłopców i 20 dziewcząt. Grupa kontrolna obejmowała 78 osób z prawidłowym słuchem w wieku od 1 roku do 35 lat (śr. 9,8 55,7 lat), w tym 49 chłopców i 29 dziewcząt. Ponad $75 \%$ osób w obu grupach było w wieku od 5 do 15 lat. Analiza statystyczna wykonana testem t-Studenta dla prób niezależnych nie wykazała istotnych statystycznie różnic w średnim wieku obu badanych grup. Warunkiem przystąpienia do badań osób z zespołem Downa było podpisanie przez opiekuna zgody na przeprowadzenie testów.

\section{trzask, $80 \mathrm{~dB} \mathrm{nHL}$}

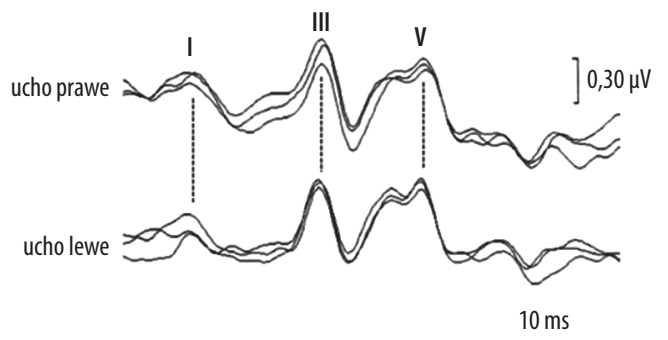

Rycina 1. Przykład wyznaczenia interwałów czasowych odpowiedzi ABR u osoby z zespołem Downa

Figure 1. Example of determination of $A B R$ interpeak-intervals in a subject with Down syndrome

\section{Metody}

Badania w grupie osób z zespołem Downa zostały wykonywane podczas snu fizjologicznego lub w stanie czuwania, w domu dziecka lub w szkole specjalnej. Czas przeprowadzenia badania ABR jednego pacjenta zawierał się w przedziale od 1 do 3 godzin. Przed przystąpieniem do badań ABR u każdego pacjenta kilka dni wcześniej wykonano otoskopię (przez lekarza laryngologa). Jeśli nie stwierdzono nieprawidłowości w obrębie przewodu słuchowego zewnętrznego oraz błony bębenkowej, podejmowano próbę wykonania tympanometrii, emisji otoakustycznych oraz rejestrację słuchowych potencjałów wywołanych pnia mózgu (ABR). Analiza wyników wszystkich badań obiektywnych słuchu będzie przedmiotem odrębnej publikacji.

Badanie słuchowych potencjałów wywołanych pnia mózgu dla trzasku o natężeniu $80 \mathrm{~dB}$ nHL przeprowadzono za pomocą urządzenia Integrity V500 firmy Vivosonic. Pasmo wzmacniacza biologicznego w badaniach ABR zawierało się w przedziale od 30 do $3000 \mathrm{~Hz}$. Bodźce prezentowano z naprzemienną polaryzacją przez słuchawki ER-3A. Częstość powtarzania bodźca wynosiła $37 /$ s, natomiast czas analizy odpowiedzi wynosił $10 \mathrm{~ms}$. W zależności od liczby artefaktów mięśniowych liczba uśrednień wynosiła od 500 do 2000. Po zarejestrowaniu odpowiedzi oznaczano za pomocą kursora szczyty fal I, III i V oraz wyznaczano wartości interwałów czasowych.

Na rycinie 1 przedstawiono przykład rejestracji odpowiedzi ABR u osoby z zespołem Downa. Jakość zapisów odpowiedzi ABR u większości pozostałych osób z zespołem Downa była zbliżona do jakości zapisu odpowiedzi przedstawionych na rycinie 1 .

\section{Wyniki}

W tabeli 1 przedstawiono średnie wartości interwałów czasowych I-III i III-V dla obojga uszu oraz wartości różnic międzyusznych obu interwałów w grupie osób z zespołem Downa. Analiza statystyczna wykonana testem t-Studenta dla prób powiązanych nie wykazała istotnych statystycznie różnic w wartościach interwałów dla obojga uszu, natomiast stwierdzono, że wartości interwału I-III są istotnie dłuższe niż wartości interwału III-V. 
Tabela 1. Średnie wartości oraz odchylenie standardowe - s.d. dla interwałów czasowych I-III i III-V dla ucha prawego i lewego w grupie osób z zespołem Downa

Table 1. Mean values and standard deviations - s.d. of intervals I-III and III-V for left and right ear in a group of subjects with Down syndrome

\begin{tabular}{lcccc} 
& \multicolumn{2}{c}{ Interwat I-III } & \multicolumn{2}{c}{ Interwat III-V } \\
\cline { 2 - 5 } & ucho prawe & ucho lewe & ucho prawe & ucho lewe \\
\hline Średnia [ms] & 2,07 & 2,09 & 1,86 & 1,86 \\
\hline s.d. [ms] & 0,13 & 0,10 & 0,11 & 0,09 \\
\hline
\end{tabular}

Tabela 2. Średnie wartości i odchylenie standardowe interwałów czasowych I-III i III-V w obu grupach osób Table 2. Mean values and standard deviation of time intervals I to III and III to V in both groups of people

\begin{tabular}{lcl}
\hline & \multicolumn{2}{c}{ Interwat czasowy } \\
\cline { 2 - 3 } & I-III & III-V \\
\hline Grupa kontrolna & $2,19 \pm 0,14 \mathrm{~ms}$ & $1,82 \pm 0,17 \mathrm{~ms}$ \\
\hline Grupa z zespotem Downa (ZD) & $2,07 \pm 0,13 \mathrm{~ms}$ & $1,85 \pm 0,11 \mathrm{~ms}$ \\
\hline
\end{tabular}

Ponieważ nie stwierdzono znaczących statystycznie różnic w wartościach interwałów I-III i III-V dla obojga uszu, dlatego wyznaczono średnie wartości interwałów dla wszystkich uszu w grupie osób z zespołem Downa oraz porównano ze średnimi wartościami interwałów w grupie kontrolnej (tabela 2). Średnia wartość interwału I-III

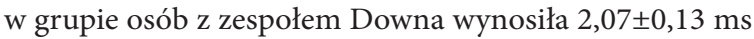
i była istotnie statystycznie $(p<0,05)$ mniejsza niż w grupie osób z zespołem Downa. Interwał III-V w grupie kontrolnej był nieznacznie krótszy niż w grupie z ZD, przy czym analiza statystyczna wykonana testem t-Studenta dla prób niezależnych wykazała, że różnice pomiędzy wartościami interwałów III-V w obu grupach nie były istotne statystycznie $(p>0,05)$. W obu grupach badanych osób średnie wartości interwału I-III były istotnie statystycznie dłuższe niż wartości średnie interwału III-V.

\section{Dyskusja}

Wyniki badań wielu autorów wskazywały na różnice $\mathrm{w}$ przewodnictwie $\mathrm{w}$ nerwie słuchowym u osób z zespołem Downa w porównaniu z osobami zdrowymi, z prawidłowym słuchem. W tabeli 3 przedstawiono przegląd prac dotyczących oceny wartości interwałów czasowych słuchowych potencjałów wywołanych pnia mózgu u osób z zespołem Downa. Do analizy wybrano tylko te prace, w których stosowano metodykę stymulacji i rejestracji ABR zbliżoną do zastosowanej w niniejszej pracy.

Squires i wsp. [28] przebadali 31 pacjentów z upośledzeniem umysłowym, w tym 16 osób z zespołem Downa. Wyniki wykazały znacząco krótsze interwały I-V u 33\% pacjentów z zespołem Downa oraz znacząco dłuższy u jednego pacjenta. W badaniach Jiang i wsp. przeprowadzonych na grupie 14 osób z zespołem Downa w wieku od 1 miesiąca do 3 lat stwierdzono krótsze interwały I-III [31]. Sersen i wsp. przeprowadzili badania w grupie 16 osób z zespołem Downa, grupę kontrolną stanowiło 46 osób. Pacjentów z zespołem Downa badano w sedacji i bez sedacji i nie stwierdzono istotnych statystycznie różnic w wartościach interwałów czasowych pomiędzy osobami z zespołem Downa a grupą kontrolną [41]. Kakigi i Kuroda zbadali 37 dorosłych osób z zespołem Downa w wieku 18-48 lat. Wartości interwałów I-III i III-V u osób z zespołem Downa były krótsze niż w grupie kontrolnej [32]. Dfaz i Zurron wykonali badania na grupie 12 osób z zespołem Downa. Wartości interwałów I-III w grupie dzieci z zespołem Downa były znacząco krótsze niż u osób z grupy kontrolnej, natomiast wartości interwałów III-V nie były istotnie statystycznie różne [29]. Kręcicki i wsp. objęli badaniem grupę 70 dzieci z zespołem Downa. Wykazali skrócone interwały I-III u dzieci do 1 r.ż. w porównaniu z wynikami starszych dzieci z zespołem Downa oraz z grupą kontrolną [36]. Badania przeprowadzone przez Yung-Jung Chen i Peng-Cheng Fang zostały wykonane $\mathrm{z}$ udziałem 55 noworodków: $30 \mathrm{z}$ zespołem Downa i 25 z grupy kontrolnej. Wyniki badań nie wykazały istotnych różnic w wartościach interwałów I-III i III-V [37].

Próbę wykonania badań u dorosłych osób zespołem Downa podjęli także Forti wsp. W badaniach wzięło udział 19 osób z zespołem Downa w wieku 18-45 lat. Do badań zakwalifikowano osoby, u których wynik audiometrii tonalnej był w zakresie normy. Wyniki badań osób z zespołem Downa wykazały istotne statystycznie różnice związane $\mathrm{z}$ płcią w zakresie interwału III-V. Interwały III-V i I-V były nieznacznie skrócone u pacjentów z zespołem Downa. Między mężczyznami i kobietami z zespołem Downa tylko wartości interwałów III-V były istotnie różne. Nie stwierdzono istotnych statystycznie różnic pomiędzy zespołem Downa a grupą kontrolną, ale znaczące różnice zaobserwowano, kiedy uwzględniono płeć badanych osób [38]. Kolejne badanie ABR u 15 noworodków z ZD w wieku od 32 do 34 tygodnia życia przeprowadziła Kittler i wsp. Wyniki badań ABR wskazały na skrócenie latencji fali III i V oraz krótsze interwały I-III, natomiast interwały III-V były w normie [42]. Najnowsze badania Sato i Suzuki wykazały u osób z zespołem Downa istotnie statystycznie skrócone wartości interwałów III-V w porównaniu z grupą kontrolną [39]. 
Tabela 3. Wyniki prac różnych autorów, w których oceniano wartości interwałów czasowych u osób z zespołem Downa oraz w grupie kontrolnej

Table 3. The results of works of various authors, which assess the value of time intervals in people with Down syndrome and a control group

\begin{tabular}{|c|c|c|c|c|c|c|}
\hline Autor & $\begin{array}{l}\text { Parametry } \\
\text { stymulacji }\end{array}$ & Grupa & $\begin{array}{l}\text { Liczba } \\
\text { osób }\end{array}$ & Wiek & $\begin{array}{c}\text { Średnie wartości } \\
\text { interwału } \\
\text { I-III }\end{array}$ & $\begin{array}{c}\text { Średnie wartości } \\
\text { interwału } \\
\text { III-V }\end{array}$ \\
\hline \multirow{2}{*}{$\begin{array}{l}\text { Squires i wsp. } \\
\text { (1980) }\end{array}$} & \multirow{2}{*}{$\begin{array}{l}\text { trzask } \\
70 \mathrm{~dB} \\
20 / \mathrm{s}\end{array}$} & Zespół Downa & 16 & $13-45$ I. & $2,1 \mathrm{~ms}$ & $1,78 \mathrm{~ms}^{*}$ \\
\hline & & Grupa kontrolna & 15 & 19-43 I. & $2,19 \mathrm{~ms}$ & $1,92 \mathrm{~ms}$ \\
\hline \multirow{2}{*}{$\begin{array}{l}\text { Jiang i wsp. } \\
\text { (1990) }\end{array}$} & \multirow{2}{*}{$\begin{array}{c}\text { trzask } \\
70 \mathrm{~dB} \mathrm{nHL}\end{array}$} & Zespół Downa & 14 & $\begin{array}{c}1 \mathrm{~m}-\mathrm{c}- \\
3 \mathrm{r.z.} .\end{array}$ & $2,25 \mathrm{~ms}^{*}$ & $1,77 \mathrm{~ms}^{*}$ \\
\hline & & Grupa kontrolna & 134 & 37-42 m-cy & $2,47 \mathrm{~ms}$ & $1,9 \mathrm{~ms}$ \\
\hline \multirow[t]{2}{*}{$\begin{array}{l}\text { Sersen i wsp. } \\
\text { (1990) }\end{array}$} & \multirow[t]{2}{*}{$\begin{array}{c}\text { trzask } \\
55,5 \mathrm{~dB} \\
10,3 / \mathrm{s}\end{array}$} & Zespół Downa & 16 & $\begin{array}{l}2-14 l . \\
7-18 I .\end{array}$ & $\begin{array}{c}\text { w sedacji } \\
\text { 2,11 ms } \\
\text { bez sedacji } \\
2,06 \mathrm{~ms}\end{array}$ & $\begin{array}{c}\text { w sedacji } \\
1,92 \mathrm{~ms} \\
\text { bez sedacji } \\
1,86 \mathrm{~ms} \\
\end{array}$ \\
\hline & & Grupa kontrolna & 46 & 7-18 I. & $2,1 \mathrm{~ms}$ & $1,86 \mathrm{~ms}$ \\
\hline \multirow{2}{*}{$\begin{array}{l}\text { Kakigi i Kuroda } \\
\text { (1992) }\end{array}$} & \multirow{2}{*}{$\begin{array}{c}\text { trzask } \\
90 \mathrm{~dB} \text { peSPL } \\
9,1 / \mathrm{s}\end{array}$} & Zespół Downa & 37 & $18-48$ I. & $2,1 \mathrm{~ms}$ & $1,84 \mathrm{~ms}$ \\
\hline & & Grupa kontrolna & 37 & $18-50 \mathrm{l}$. & $2,18 \mathrm{~ms}$ & $1,92 \mathrm{~ms}$ \\
\hline \multirow{2}{*}{$\begin{array}{l}\text { Dfaz i Zurron } \\
\text { (1995) }\end{array}$} & \multirow{2}{*}{$\begin{array}{l}\text { trzask } \\
45 \mathrm{~dB} \\
10 / \mathrm{s}\end{array}$} & Zespół Downa & 12 & $11-19 \mid$. & $1,95 \mathrm{~ms}^{*}$ & $1,93 \mathrm{~ms}$ \\
\hline & & Grupa kontrolna & 12 & $11-19 \mid$. & $2,22 \mathrm{~ms}$ & $1,85 \mathrm{~ms}$ \\
\hline \multirow[t]{2}{*}{$\begin{array}{l}\text { Kręcicki i wsp. } \\
\text { (2004) }\end{array}$} & \multirow[t]{2}{*}{$\begin{array}{l}\text { trzask } \\
70 \mathrm{~dB} \\
20 / \mathrm{s}\end{array}$} & Zespół Downa & 70 & 2 m-ce- $17 \mathrm{l}$. & $\begin{array}{c}2,22 \mathrm{~ms}^{*} \\
\text { (do } 1 \mathrm{r} . \dot{z} \text {.) } \\
\text { 2,43 } \mathrm{ms}^{\star *} \\
\text { (powyżej } \\
1 \text { r.ż.) }\end{array}$ & $\begin{array}{c}1,85 \mathrm{~ms} \\
\text { (do } 1 \mathrm{r} . \dot{z} .) \\
1,79 \mathrm{~ms} \\
\text { (powyżej } 1 \text { r.ż.) }\end{array}$ \\
\hline & & Grupa kontrolna & 60 & $\begin{array}{l}30 \text { osób do } 1 \text { r.ż. } \\
\text { oraz } 30 \text { osób } \\
\text { powyżej } 1 \text { r.ż. }\end{array}$ & $\begin{array}{c}2,58 \mathrm{~ms} \\
\text { (do } 1 \text { r.ż.) } 2,26 \mathrm{~ms} \\
\text { (powyżej } 1 \text { r.ż.) }\end{array}$ & $\begin{array}{c}2,04 \mathrm{~ms} \\
\text { (do } 1 \text { r.ż.) } \\
1,81 \text { ms (powyżej } 1 \text { r.ż.) }\end{array}$ \\
\hline \multirow{2}{*}{$\begin{array}{l}\text { Yung-Jung i Peng- } \\
\text { Cheng (2005) }\end{array}$} & \multirow{2}{*}{$\begin{array}{c}\text { trzask } \\
70 \mathrm{~dB} \mathrm{nHL} \\
13,1 / \mathrm{s}\end{array}$} & Zespół Downa & 30 & $\begin{array}{l}6-18 \\
m-c y\end{array}$ & $2,43 \mathrm{~ms}$ & $1,99 \mathrm{~ms}$ \\
\hline & & Grupa kontrolna & 25 & $\begin{array}{l}7-16 \\
m-c y\end{array}$ & $2,43 \mathrm{~ms}$ & $2,06 \mathrm{~ms}$ \\
\hline \multirow{2}{*}{$\begin{array}{l}\text { Forti i wsp. } \\
\text { (2008) }\end{array}$} & \multirow{2}{*}{$\begin{array}{l}70 \mathrm{~dB} \\
21 / \mathrm{s}\end{array}$} & Zespół Downa & 19 & $18-45 \mid$. & $\begin{array}{l}\text { dz. } 1,97 \mathrm{~ms} \\
\text { ch. } 2,13 \mathrm{~ms}\end{array}$ & $\begin{array}{l}\text { dz. } 1,68 \mathrm{~ms}^{*} \\
\text { ch. } 1,77 \mathrm{~ms}^{*}\end{array}$ \\
\hline & & Grupa kontrolna & 19 & 24-40 l. & $\begin{array}{l}\text { dz. } 2,05 \mathrm{~ms} \\
\text { ch. } 2,08 \mathrm{~ms}\end{array}$ & $\begin{array}{l}\text { dz. } 1,81 \mathrm{~ms} \\
\text { ch. } 1,88 \mathrm{~ms}\end{array}$ \\
\hline \multirow{2}{*}{$\begin{array}{l}\text { Kittler i wsp. } \\
\text { (2009) }\end{array}$} & \multirow{2}{*}{$80 \mathrm{~dB} 12,9 / \mathrm{s}$} & Zespół Downa & 15 & $32-42$ tydz. & $2,66 \mathrm{~ms}^{*}$ & $2,26 \mathrm{~ms}$ \\
\hline & & Grupa kontrolna & 15 & 32-42 tyg. & $2,91 \mathrm{~ms}$ & $2,35 \mathrm{~ms}$ \\
\hline \multirow{2}{*}{$\begin{array}{l}\text { Sato i Suzuki } \\
\text { (2014) }\end{array}$} & \multirow{2}{*}{ trzask } & Zespół Downa & 23 & $20,6 \pm 6$ dni & $2,8 \mathrm{~ms}$ & $2,06 \mathrm{~ms}^{*}$ \\
\hline & & Grupa kontrolna & 23 & $20,6 \pm 6 \mathrm{dni}$ & $2,9 \mathrm{~ms}$ & $2,25 \mathrm{~ms}$ \\
\hline
\end{tabular}

* Wartość interwału istotnie statystycznie krótsza w grupie z zespołem Downa; ${ }^{*}$ - wartość interwału istotnie statystycznie dłuższa w grupie z zespołem Downa. dz. - dziewczynki; ch. - chłopcy; tyg. - tygodnie; tydz. - tydzień; r.ż. - rok życia.

\section{Wnioski}

Wyniki badań uzyskane w niniejszej pracy pokazały, że średnia wartość interwału I-III w grupie osób z zespołem Downa jest istotnie statystycznie mniejsza niż w grupie kontrolnej. Zatem uzyskane wyniki są zgodne z wynikami prac Kittler [42], Kręcickiego [36], Jiang [31], Dfaz [29]. Należy jednak zauważyć, że większość przytoczonych publikacji, poza pracą Kręcickiego [36], była wykonana z udziałem niezbyt licznych grup osób z zespołem Downa, co mogło mieć znaczenie dla uzyskanych wyników. Ogólnie, wyniki niniejszej pracy wykazały, że przewodnictwo neuronalne w nerwie słuchowym u osób z zespołem Downa jest nieznacznie szybsze od przewodnictwa stwierdzanego u osób zdrowych z prawidłowym słuchem. Być może, tak jak to sugerują inni badacze, ma to związek z mniejszymi rozmiarami pnia mózgu, deficytami w ślimaku. 


\section{Piśmiennictwo:}

1. Korenberg JR, Chen XN, Schipper R. i wsp. Down syndrome phenotypes: the consequences of chromosomal imbalance. Proc Natl Acad Sci USA, 1994; 91(11), 4997-5001.

2. Korniszewski L. Dziecko z zespołem wad wrodzonych. Diagnostyka dysmorfologiczna, Warszawa: PZWL; 2004.

3. Opitz JM, Gilbert-Barness EF. Reflections of the pathogenesis of Down syndrome. Am Med Genet Supp, 1990; 7: 38-51.

4. Keiser H, Montague J, Wold D Maune D, Pattison D. Hearing loss of Down syndrome adults. Am J Ment Defic, 1981; 85: 467-72.

5. Szyfter W, Łączkowska-Przybylska J. Hearing impairment in children with Down's syndrome. Otolaryngol Pol, 1999; 13: 83-86.

6. Hassman E, Skotnicka B, Midro A, Musiatowicz M. Distortion products otoacustic emissions in diagnosis of hearing loss in Down Syndrome. Int J Pediatr Otorhinolaryngol, 1988; 45: 199-206.

7. Davis B. Auditory disorders In Down's syndrome. Scan Audiol Suppl, 1998; 30: 65-68.

8. Iino Y, Imamura Y, Harigi S, Tanaka Y. Efficacy of tympanostomy tube insertion for ototis media with effusion in children with Down syndrome. Int J Pediatr Otorhinolaryngol, 1999; 49: 143-49.

9. Kaga K, Marsh R. Auditory brainstem responses in young children with Down's syndrome. Int J Pediatr Otolaryngol, 1986; 11: 29-38.

10. Murizi M, Ottaviani F, Paludetti G, Lungarotti S. Audiological findings in Down's children. Int J Pediatr Otolaryngol, 1985; 9: 227-32.

11. Pappas DG, Flexer C, Shackelford MA. Otological and habilitativ management of children with Down Syndrome. Laryngoscope, 1994; 104: 1065-70.

12. Roizen JR, Wolters C, Nicol T, Blondis TA. Hearing loss in children with Down syndrome. J Pediatr, 1993; 123: 10-12.

13. Shott SR, Joseph A, Heithaus D. Hearing loss in children with Down syndrome. Int. Pediatr Otorhinolaryngol, 2001; 61: 199-205.

14. Pilecki W, Sadowska L, Mysłek M. Efektywność wczesnej neurostymulacji rozwoju wg Wrocławskiego Modelu Usprawniania dzieci z zespołem Downa w świetle badań bioelektrycznych mózgu. Fizjoterapia Polska, 2002; 2(2): 99-107.

15. Ferii R, Del Gracco S, Elia M, Musumeci SA, Stefani MC. Age, sex and mental retardation related changes of brainstem auditory evoked potentials in Down's syndrome. Ital J Neurol Sci, 1995; 16: 377-83.

16. Folsom RC, Widen JE, Wilson WR. Auditory brainstem responses in infants with Down's syndrome. Arch Otolaryngol, 1983; 109: 607-10.

17. Minczakiewicz EM. Gdy u dziecka rozpoznano zespół Downa. Kraków: Wyd. Naukowe WSP; 1994.

18. Petit TL, Le Boutillier JC, Alfano DP i wsp. Synaptic development in the human fetus: a morphometric analysis of normal and Down's syndrome neocortex. Exp Neurol, 1984; 83, 13-23.

19. Sadowska L, Gruna-Ożarowska A, Krefft A, Badowski R. Syntetyczna ocena zmian strukturalnych mózgu w badaniu magnetycznym rezonansem jądrowym (MRI) u leczonych osób z zespołem Downa. Przegląd Medyczny Uniwersytetu Rzeszowskiego, 2005; 3(3): 252-61.
20. Schmidt-Sidor B, Wiśniewski KE, Shepard TH i wsp. Brain growth in Down syndrome subjects 15 to 22 weeks of gestational age and birth to 60 months. Neuropathology, 1990; 9(4): 181-90.

21. Wiśniewski KE, Dalton AJ, McLachlan C i wsp. Alzheimer disease in Down's syndrome clinicopathologic studies. Neurology, 1985; 35: 957-61.

22. Wiśniewski KE, Laure-Kamionowska M, Connell F i wsp. Neuronal density and synaptogenesis in the postnatal stage of brain maturation in Down's syndrome. W: Epstein CL, red. The neurobiology of Down's syndrome. New York: Raven Press; 1986, s. 29-44.

23. Wiśniewski K, Schmid-Sidor B. Postnatal delay of myelin formation in brains from Down syndrome infants and children. Neuropathology, 1989; 8: 55-62.

24. Wiśniewski KE: Down syndrome children often have brain with maturation delay, retardation of growth and cortical dysgenesis. Am J Med Genet B Neuropsychiatr Genet, Suppl, 1990; 7: 274-81.

25. Wiśniewski KE, Kida E. Abnormal neurogenesie and synaptogenesis in Down syndrome brain. Dev Brain Dysfunct, 1994; 7: 289-301.

26. Kochanek K. Słuchowe potencjały wywołane. W: Audiologia Kliniczna. Łódź; 2005, s. 167.

27. Pilecki W. Ustalanie się dróg słuchowych u noworodków w świetle badań wywołanych potencjałów z pnia mózgu. Praca doktorska. Wrocław: Akademia Medyczna; 1989.

28. Squires N, Aine C, Buchwald J, Norman R, Galbraith G. Auditory brainstem responses abnormalities in severely and profoundly retarded adults. Electroencephalogr Clin Neurophysiol, 1980; 50: 172-85.

29. Dfaz F, Zurron M. Auditory evoked potentials in Down's syndrome. Electroencephalogr Clin Neurophysiol, 1995; 526-37.

30. Ferii R, Del Gracco S, Elia M, Musumeci SA, Stefani MC. Age, sex and mental retardation related changes of brainstem auditory evoked potentials in Down's syndrome. Ital J Neurol Sci, 1995; 16: 377-83.

31. Jiang ZD, Wu YY, Liu XY. Early development of brainstem auditory evoked potentials in Down's syndrome. Early Hum Dev, 1990; 23: 41-51.

32. Kakigi K, Kuroda Y. Breinstem auditory evoked potentials in adults with Down's syndrome. Electroencephalogr Clin Neurophysiol, 1992; 84: 293-95.

33. Crome L, Cowie V, Slater E. A statistical note on cerebelar and brain-stem weight in mongolism. J Ment Defic Res, 1966; 10: 69-72.

34. Poblano A, Munoz-Hernandez SE, Arias-Aranda I, CastroCue-De Carpizo L, Montes de Oca-Fernandez E, G de laVega-De Teyssier. Brain-stem auditory evoked potentials andmedian latency in children with Down's syndrome. Bol Med Hosp Infant Mex, 1991; 48: 793-99.

35. Intrapiromkul J, Aygun N, Tunkel DE, Carone M, Yousem DM. Inner ear anomalies seen on CT images in people with Down syndrome. Pediatr Radiol, 2012; 42(12): 1449-55.

36. Kręcicki T, Zalesska-Kręcicka M, Kubiak K, Gawron W. Brain auditory evoked potentials in children with Down syndrome. Int J Pediatr Otorhinolaryngol, 2005; 69: 615-20.

37. Yung-Jung Ch, Peng-Cheng F. Sensory evoked potentials in infants with Down Syndrome. Acta Pediatrica, 2005; 94: 1615-18. 
38. Forti S, Amadeo Ch. Auditory brainstem responses (ABR) in normal hearing adult subjects with Down's syndrome. Brain Res, 2008; 1233: 58-62.

39. Satoa M, Suzukia Sh. Auditory Brainstem Responses in newborns with Down Syndrome at a Japanese Perinatal Center. Int J Clin Pediatr, 2014; 3(3): 69-71.

40. Saliba I, Sbeity S, El-Zir E i wsp. Down Syndrome: An electrophysiological and radiological profile. Laryngoscope, 2014; 124: 141-47.
41. Sersen EA, Heaney G, Clausen J, Belser R, Rainbow S. Brainstem auditory-evoked responses with and without sedation in autism and Down's syndrome. Biol Psychiatry, 1990; 27(8): 834-40.

42. Kittler P, Phan T, Gardner J. Auditory brainstem evoked responses in newborns with Down Syndrome. Am J Intellect Dev Disabil, 2009; 114(6): 393-400. 